\title{
EVALUASI SISTEM PENANGKAL PETIR EKSTERNAL DI GEDUNG REKTORAT UNIVERSITAS NEGERI YOGYAKARTA
}

\author{
Rohani $^{1}$, Nurhening Yuniarti ${ }^{2}$ \\ ${ }^{1,2}$ Jurusan Pendidikan Teknik Elektro FT UNY \\ Email: roroft454@gmail.com
}

\begin{abstract}
The aims of this research are to evaluate the external lightning rod system (SPP) which was set and to find the effectiveness of the conventional lightning rod system by using electrostatic. Methods used in this research are data collection and data analysis. The data collecting methods consist of: 1) Observation, 2) Measurement, 3) Literary review, 4) Interview. The data analyses consist of: 1) Needs, Lightning protected building, 2) Determining the protection radius, 3) Down conductor, 4) Grounding system. This evaluation result shows that: 1) Based on the UNY Rectorate's tallest building, it is necessary to have a lightning rod system with the protection level of III, 2) The usage of the conventional lightning rod with the corner protection method still need to increase the protection by adding 27 lightning rods. On the other hand, the usage of electrostatic lightning rod based on the calculation analysis NFC 17-102 standard, has a radius of $100 \mathrm{~m}$, yet it could protect the whole UNY rectorate buildings and the surrounding areas, 3) The down conductor and grounding system earth termination, either conventional lightning rod or electrostatic overall has qualified the standard.
\end{abstract}

Keywords: External Lightning Rod, Electrostatic Lightning Rod, Conventional Lightning Rod

\begin{abstract}
ABSTRAK
Tujuan penelitian ini adalah untuk mengevaluasi sistem penangkal petir (SPP) eksternal yang telah terpasang dan untuk mengetahui efektifitas sistem penangkal petir konvensional dengan elektrostatis. Dalam penelitian ini metode evaluasi dilakukan dengan metode pengumpulan data dan analisa data. Metode pengumpulan data terdiri dari: 1) Observasi, 2) Pengukuran, 3) Studi pustaka, dan 4) Wawancara. Analisa data terdiri dari: 1) Kebutuhan, bangunan akan proteksi petir, 2) Menentukan radius proteksi, 3) Konduktor penyalur, dan 4) Terminasi bumi. Hasil evaluasi menunjukkan bahwa: 1) Berdasarkan gedung tertinggi gedung Rektorat UNY sangat memerlukan adanya sistem penangkal petir dengan tingkat proteksi petir level III, 2) Penggunaan penangkal petir konvensional dengan metode sudut proteksi masih membutuhkan peningkatan proteksi berupa penambahan batang penangkal petir sebanyak 27 batang, sedangkan penggunaan penangkal petir elektrostatis berdasarkan analisa perhitungan standar NFC 17-102 memiliki radius $100 \mathrm{~m}$, namun sudah mampu melindungi keseluruhan gedung Rektorat UNY dan daerah sekitarnya, dan 3) Konduktor penyalur dan terminasi bumi baik penangkal petir konvensional maupun elektrostatis keseluruhan sudah memenuhi standar.
\end{abstract}

Kata kunci: Penangkal Petir Eksternal, Penangkal Petir Elektrostatis, Penangkal Petir Konvensional

\section{PENDAHULUAN}

Mengingat letak geografis Indonesia yang dilalui garis katulistiwa menyebabkan Indonesia beriklim tropis, akibatnya Indonesia memiliki hari guruh rata-rata pertahun yang sangat tinggi. Demikian memiliki resiko lebih besar mengalami kerusakan akibat terkena sambaran petir.
Pembangunan gedung bertingkat menjadi solusi karena semakin sempitnya lahan tanah. Namun disisi lain, dengan semakin banyak berdirinya bangunan bertingkat, beberapa permasalahan mengenai keamanan bangunan menjadi penting untuk diperhatikan, karena bangunan bertingkat lebih rawan mengalami gangguan, baik gangguan secara mekanik maupun gangguan alam. Salah satu gangguan alam yang sering terjadi adalah sambaran petir. 
Gedung Rektorat Universitas Negeri Yogyakarta merupakan salah satu gedung bertingkat yang ada di daerah kota Yogyakarta. Dimana gedung tersebut merupakan gedung yang memiliki intensitas kegiatan akademik dan birokrasi yang tinggi sehingga memerlukan keamanan dan kenyaman dari berbagai gangguan salah satunya gangguan alam yaitu sambaran petir. Untuk menghindari bahaya sambaran petir maka diperlukan sistem penangkal petir.

Menyadari hal tersebut, pihak instansi telah memasang sistem penangkal petir di gedung Rektorat. Suatu sistem tentu memiliki karakteristik dan klasifikasi tertentu untuk dapat benjalan dengan baik. Sehubungan dengan hal tersebut, perlu diketahui karakteristik dan klasifikasi sistem penangkal petir yang digunakan pihak kampus UNY yang dipasang pada gedung Rektorat, untuk kemudian dapat analisisa kesesuainya beradasarkan standar.

Permasalahan pada gedung Rektorat Universitas Negeri Yogyakarta diantaranya radius proteksi yang digunakan untuk menyatakan lingkup penangkal petir, yaitu seberapa banyak suatu daerah yang dapat dicakup oleh penangkal petir sehingga pada daerah tersebut mempunyai kemungkinan kecil untuk disambar petir. Konduktor penyalur adalah bagian dari sistem penangkal petir yang dimaksudkan untuk melewatkan arus petir dari sistem terminasi udara ke sistem terminasi bumi, mengingat sambaran listrik dapat menimbulkan induksi terhadap peralatanperalatan listrik yang terdapat di dalam ataupun di sekitar bangunan yang diproteksi, maka pemilihan bahan dan ukuran minimum konduktor penyalur harus sesuai dengan ketentuan standar. Sistem terminasi bumi adalah bagian dari sistem penangkal petir eksternal yang dimaksudkan untuk melakukan dan menetralkan arus petir ke bumi, tampa menimbulkan bahaya bagi orang atau kerusakan pada instalasi di dalam struktur yang akan dilindungi.

\section{METODE}

Teknik pengumpulan data dalam yang dilakukan dengan menggunakan metode observasi, pengukuran, studi pustaka dan wawancara. Observasi dilakukan dengan melakukan pengamatan secara langsung terhadap objek yang dievaluasi. Hasil observasi antara lain; gambar perncanan, data tinggi, lebar dan panjang bangunan dan data hari guruh. Pengukuran dilakukan untuk mendapatkan data panjang terminasi penangkal petir konvensional dan pengukuran tahanan pentanahan. Studi pustaka dilakukan dengan mempelajari seluruh aspek teoritis dari berbagai referensi untuk memperoleh rumusan dan standar-standar yang digunakan dalam evaluasi sistem penangkal petir yang terpasang. Adapun standar yang digunakan adalah Standar Nasional Indonesia SNI 03-7015-2004, NFC 17-102, PUIL 2000 dan Departemen Perkerjaan Umum RI No 378/KPTS/1987. Wawancara dilakukan guna melengkapi data-data yang dibutuhkan sekiranya belum tertulis dengan mengajukan pertanyaan-pertanyaan yang berhubungan dengan objek yang dievaluasi kepada pihakpihak yang bersangkutan. Selain kepada pihak yang bersangkutan dengan objek yang dievaluasi juga dilakukan wawancara kepada pihak lain yang memahami tentang masalah yang berhubungan dengan objek yang dievaluasi.

Langkah awal pada tahap evaluasi yakni dimulai dengan pengambilan data. Pada tahapan ini data yang diperlukan meliputi data hasil observasi, pengukuran dan studi pustaka. Data observasi meliputi denah gedung dan Hari Guruh. Denah gedung digunakan untuk menghitung luas daerah yang memiliki angka sambaran petir dan untuk menganalisa radius proteksi serta penentuan letak terminasi udara baik dari kedua metode yang digunakan pada tiap-tiap gedung. Data jenis bahan bangunan dan hari guruh digunakan sebagai penentuan besarnya kebutuhan bangunan akan adanya sistem penangkal petir berdasarkan indeksindeks standar yang digunakan, selain itu data 
hari guruh juga digunakan untuk menghitung besarnya kerapatan sambaran petir ke tanah. Studi pustaka dilakukan untuk memperoleh referensi mengenai rumusan-rumusan serta standar yang akan digunakan untuk menentukan radius proteksi, minimum bahan konduktor penyalur dan tahan pentanahan.

Langkah selanjutnya adalah analisa data. Pada tahap ini dilakukan analisa perhitungan terhadap data-data yang diperoleh untuk analisa penentuan tingkat proteksi berdasarkan standar (SNI 037014.1-2004). Setelah mengetahui tingkatan proteksi langkah selanjutnya yaitu melakukan analisa perhitungan radius proteksi baik penangkal petir konvensional maupun nonkonvensional (elektrostatis) berdasarkan standar (SNI 037014.1-2004) dan standar French NFC 17-102 September 2011, untuk konduktor penyalur berdasarkan standar (SNI 037014.1-2004) dilihat dari ukuran minimum bahan yang digunakan dan untuk terminasi bumi berdasarkan Peraturan Umum Instalasi Listrik (PUIL) 2000 Pasal 3. 13.2. 10 dilihat dari tahanan pentanahan yang didapatkan dari hasil pengukuran. Apabila hasil dari analisa data tidak sesuai dengan standar maka dilakukan evaluasi berdasarkan standar yang teleh ditetapkan sehingga bangunan keseluruhan terlindungi.

\section{HASIL DAN PEMBAHASAN}

Besarnya bangunan akan sistem penangkal petir berdasarkan gedung tertinggi gedung Rektorat tampak depan (selatan)

Besarnya kebutuhan suatu bangunan akan adanya sistem penangkal petir dapat ditentukan berdasarkan indeks-indeks yang menyatakan faktor-faktor tertentu seperti pada Tabel 1 sampai 5. (Departemen Pekerjaan Umum RI, 18-20)

Tabel 1. Indeks A: Bahaya Berdasarkan Jenis Bangunan

\begin{tabular}{|l|c|}
\hline \multicolumn{1}{|c|}{ Penggunaan dan Isi } & Indeks A \\
\hline Bangunan biasa yang tidak perlu diamankan baik bangunan maupun isinya. & -10 \\
\hline $\begin{array}{l}\text { Bangunan dan isinya jarang dipergunakan, misalnya di tengah sawah atau ladang, } \\
\text { menara atau tiang dari metal. }\end{array}$ & 0 \\
\hline $\begin{array}{l}\text { Bangunan yang berisi peralatan sehari-hari atau tempat tinggal, misalnya rumah } \\
\text { tinggal, industri kecil atau stasiun kereta api. }\end{array}$ & 1 \\
\hline $\begin{array}{l}\text { Bangunan atau isinya cukup penting, misalnya menara air, took barang-barang } \\
\text { berharga, dan kantor pemerintah. }\end{array}$ & 2 \\
\hline $\begin{array}{l}\text { Bangunan yang berisi banyak sekali orang, misalnya bioskop, sarana ibadah, } \\
\text { sekolah, dan monument sejarah yang penting. }\end{array}$ & 3 \\
\hline \begin{tabular}{l} 
Instalasi gas, minyak atau bensin, dan rumah sakit. \\
\hline $\begin{array}{l}\text { Bangunan yang mudah meledak dan dapat menimbulkan bahaya yang tidak } \\
\text { terkendali bagi sekitarrya, misalnya instalasi nuklir. }\end{array}$
\end{tabular} & 15 \\
\hline
\end{tabular}

Tabel 2. Indeks B: Bahaya Berdasarkan Kontruksi Bangunan

\begin{tabular}{|l|c|}
\hline \multicolumn{1}{|c|}{ Kontruksi Bangunan } & Indeks B \\
\hline Seluruh bangunan terbuat dari logam dan mudah menyalurkan listrik. & 0 \\
\hline $\begin{array}{l}\text { Bangunan dengan konstruksi beton bertulang atau rangka besi dengan atap } \\
\text { Logam }\end{array}$ & 1 \\
\hline $\begin{array}{l}\text { Bangunan dengan konstruksi beton bertulang. kerangka besi dan atap bukan } \\
\text { logam. }\end{array}$ & 2 \\
\hline Bangunan kayu dengan atap bukan logam & 3 \\
\hline
\end{tabular}


Tabel 3. Indeks C: Bahaya Berdasarkan Tinggi Bangunan

\begin{tabular}{|c|c|c|}
\hline Tinggi Bangunan & $(\mathbf{m})$ & Indeks C \\
\hline Sampai dengan & 6 & 0 \\
\cline { 2 - 3 } & 12 & 2 \\
\cline { 2 - 3 } & 17 & 3 \\
\cline { 2 - 3 } & 27 & 4 \\
\cline { 2 - 3 } & 35 & 5 \\
\cline { 2 - 3 } & 50 & 6 \\
\cline { 2 - 3 } & 70 & 7 \\
\cline { 2 - 3 } & 100 & 8 \\
\cline { 2 - 3 } & 140 & 9 \\
\cline { 2 - 3 } & 200 & 10 \\
\hline
\end{tabular}

Tabel 4. Indeks D: Bahaya Berdasarkan Situasi Bangunan

\begin{tabular}{|l|c|}
\hline \multicolumn{1}{|c|}{ Situasi bangunan } & Indeks D \\
\hline $\begin{array}{l}\text { Di tanah datar pada semua } \\
\text { ketinggian }\end{array}$ & 0 \\
\hline $\begin{array}{l}\text { Di kaki bukit sampai \% tinggi bukit } \\
\text { atau di pegunungan sampai 1000 } \\
\text { meter. }\end{array}$ & 1 \\
\hline $\begin{array}{l}\text { Di puncak gunung atau pegunungan } \\
\text { yang lebih dari 1000 meter. }\end{array}$ & 2 \\
\hline
\end{tabular}

Tabel 5. Indeks E: Bahaya Berdasarkan Pengaruh Kilat/ Hari Guruh

\begin{tabular}{|c|c|}
\hline Hari guruh per tahun & Indeks E \\
\hline 2 & 0 \\
\hline 4 & 1 \\
\hline 8 & 2 \\
\hline 16 & 3 \\
\hline 32 & 4 \\
\hline 64 & 5 \\
\hline 125 & 6 \\
\hline 256 & 7 \\
\hline
\end{tabular}

Dengan memperhatikan keadaan di tempat yang hendak dicari tingkat resikonya dan kemudian menjumlahkan indeks-indeks tersebut diperoleh suatu perkiraan bahaya yang ditanggung bangunan dan tingkat pengamanan yang harus diterapkan berdasarkan pada Tabel 6 di bawah ini.
Tabel 6. Indeks R: Perkiraan Bahaya Sambaran Petir

\begin{tabular}{|lr|l|l|}
\hline \multicolumn{2}{|c|}{$\begin{array}{l}\text { R = } \\
\text { A+B+C+D+E }\end{array}$} & $\begin{array}{l}\text { Perkiraan } \\
\text { Bahaya }\end{array}$ & Pengamanan \\
\hline Di bawah & 11 & Diabaikan & Tidak perlu \\
\hline $\begin{array}{l}\text { Sama } \\
\text { dengan }\end{array}$ & 11 & $\begin{array}{l}\text { Kecil } \\
\text { Sedang }\end{array}$ & $\begin{array}{l}\text { Tidak perlu } \\
\text { Agak dianjurkan } \\
\end{array}$ \\
& 13 & Agak besar & Dianjurkan \\
Besar & Sangat dianjurkan \\
\hline $\begin{array}{l}\text { Lebih } \\
\text { dari }\end{array}$ & 14 & $\begin{array}{l}\text { Sangat } \\
\text { besar }\end{array}$ & Sangat perlu \\
\hline
\end{tabular}

Nilai indeks pada gedung Rektorat

Universitas Negeri Yogyakarta tampak depan (selatan) tahap II berdasarkan Pedoman Perencanaan Penangkal petir adalah sebagai berikut:

a. Berdasarkan Tabel 1 gedung Rektorat Universitas Negeri Yogyakarta tampak depan (utara) memiliki indeks A sebesar 3 yakni bangunan yang berisi banyak sekali orang, misalnya bioskop, sarana ibadah, sekolah, dan monumen sejarahyang penting

b. Berdasarkan Tabel 2 gedung Rektorat Universitas Negeri Yogyakarta tampak depan (utara) memiliki indeks B sebesar 2 yakni bangunan dengan konstruksi beton bertulang atau rangka besi dan atap bukan logam.

c. Berdasarkan Tabel 3 gedung Rektorat Universitas Negeri Yogyakarta tampak depan (utara) memiliki indeks $\mathrm{C}$ sebesar 4 yakni tinggi bangunan sampai 35 meter.

d. Berdasarkan Tabel 4 gedung Rektorat Universitas Negeri Yogyakarta tampak depan (utara) memiliki indeks D sebesar 0 yakni di tanah datar pada semua ketinggian.

e. Hari guruh di Daerah Istimewa Yogyakarta (DIY) sebanyak 256 hari/tahun, maka berdasarkan Tabel 5 gedung Rektorat Universitas Negeri Yogyakarta memiliki indeks E sebesar 8.

Perkiraan bahaya sambaran petir diperoleh berdasarkan Pedoman Perencanaan 
Penangkal petir yaitu dengan menjumlahkan seluruh nilai dari indeks di atas dengan:

$$
\begin{aligned}
& \mathrm{R}=\mathrm{A}+\mathrm{B}+\mathrm{C}+\mathrm{D}+\mathrm{E} \\
& \mathrm{R}=3+2+4+0+8 \\
& \mathrm{R}=17 \\
& \text { Perkiraan sambaran petir } \mathrm{R}=17,
\end{aligned}
$$
berdasarkan pedoman Perencanan Penangkal Petir nilai tersebut menunjukan gedung Rektorat memiliki bahaya sambaran petir sangat besar, sehingga sangat perlu adanya sistem penangkal petir.

Perhitungan tingkat proteksi perhitungan tingkat proteksi ditentukan dengan Standar Nasional Indonesia (SNI) 03-7014.1-2004 dengan menggunakan data hari guruh, data ukuran bangunan/daerah, area proteksi, frekuensi sambaran langsung setempat $\left(N_{d}\right)$, dan frekuensi sambaran tahunan $\left(N_{c}\right)$ yang diperbolehkan pada struktur, dengan terlebih dahulu menghitung kerapatan sambaran ke $\operatorname{tanah}\left(N_{g}\right)$.

Besarnya sambaran petir ketanah $\mathrm{Ng}$ dapat dihitung:

$$
\begin{aligned}
& N_{g}=4 \cdot 10^{-2} \cdot \mathrm{Td}^{1.25} / \mathrm{km}^{2} \text { per tahun } \\
& N_{g}=4 \cdot 10^{-2} \cdot 264^{1.25} / \mathrm{km}^{2} / \text { tahun } \\
& N_{g}=42,56 \text { per } \mathrm{km}^{2} \text { per tahun }
\end{aligned}
$$

Area cakupan ikivalen Ae dapat dihitung sebagai berikut:

$$
\begin{aligned}
A_{e}= & \left.(\mathrm{ab}+6 \mathrm{~h}+(\mathrm{p}+\mathrm{l}))+\left(3,14 \cdot 9 \mathrm{~h}^{2}\right)\right) \\
= & (1487,5+6(26,6)+76,5) \\
& \left.+\left((3,14) \cdot(9) \cdot(26,6)^{2}\right)\right) \\
A_{e}= & 21.718,74 \mathrm{~m}^{2}
\end{aligned}
$$

Jumlah rata-rata frekuensi sambaran petir dapat dihitung:

$$
\begin{aligned}
& N_{d}=N_{g} \times A_{e} \times 10^{-6} \\
& N_{d}=42,56 \times 21.718,74 \times 10^{-6} \\
& N_{d}=0,92 \text { sambaran petir per tahun }
\end{aligned}
$$

Dari data Stasiun Meteorologi, Kamatologi dan Geofisika Provinsi DIY diperoleh nilai frekuensi sambaran petir tahunan setempat $\left(N_{c}\right)$ yang diperbolehkan sebesar $10^{-1}$ / tahun. Karena nilai $N d$ lebih besar dari nilai $N c$, maka nilai efisiensi adalah:

$$
\begin{aligned}
& \mathrm{E} \geq 1-\frac{N c}{N d} \\
& \mathrm{E} \geq 1-\frac{10^{-1}}{0,92} \\
& \mathrm{E} \geq 0,89=89 \%
\end{aligned}
$$

Dengan demikian nilai E sebesar 0,89 berdasarkan pada Tabel 7 nilai E 0,89 berada ditingkat proteksi III dengan nilai efisiensi diantara $80 \%-90 \%$. Oleh karena itu tingkat proteksi pada gedung Rektorat UNY tampak depan (selatan) tahap II yang sesuai adalah tingkat III.

Jika dilakukan analisa perhitungan serupa dengan langkah-langkah di atas menggunakan

\begin{tabular}{|c|c|c|c|c|c|c|c|c|}
\hline \multirow{3}{*}{ Posisi Gedung } & \multicolumn{3}{|c|}{$\begin{array}{c}\text { Parameter } \\
\text { Gedung }\end{array}$} & \multicolumn{4}{|c|}{ Parameter SNI 2004} & \multirow{3}{*}{$\begin{array}{l}\text { Tingkat } \\
\text { proteksi }\end{array}$} \\
\hline & $\mathbf{P}$ & I & $\mathbf{T}$ & Ae & $\mathrm{Ng}$ & Nd & $\mathbf{E}$ & \\
\hline & (m) & (m) & (m) & $\left(\mathrm{m}^{2}\right)$ & $\left(\mathrm{km}^{2} / \mathrm{thn}\right)$ & (./th) & & \\
\hline \multicolumn{9}{|l|}{ Depan (selatan) } \\
\hline - Tahap I & 26 & 26 & 20,5 & 12675,26 & 42,56 & 0,53 & 81 & III \\
\hline - Tahap II & 35 & 41,5 & 26,6 & 21718,74 & 42,56 & 0,92 & 89 & III \\
\hline - Tahap III & 26 & 26 & 20,5 & 12675,26 & 42,56 & 0.53 & 81 & III \\
\hline Samping (timur) & 27 & 18 & 16 & 9340,45 & 42,56 & 0,39 & 74 & IV \\
\hline Sampig (barat) & 27 & 18 & 16 & 9340,45 & 42,56 & 0,39 & 74 & IV \\
\hline Depan (utara) & 40 & 18 & 20,78 & 13188,35 & 42,56 & 0,56 & 82 & III \\
\hline
\end{tabular}
data Hari Guruh sebesar 264, Nc sebesar $10^{-1}$ dengan panjang dan lebar bangunan yang berbeda serta ketinggian berbeda - beda, diperoleh data yang dirincikan dalam Tabel 8 .

Tabel 7. Efisiensi Sistem Proteksi Petir

\begin{tabular}{|c|c|}
\hline Tingkat Proteksi & $\begin{array}{c}\text { Efisiensi Sistem Proteksi Petir } \\
\text { (E) }\end{array}$ \\
\hline I & 0,98 \\
\hline II & 0.95 \\
\hline III & 0,90 \\
\hline IV & 0,80 \\
\hline
\end{tabular}

Sumber: BSN, (2004:13)

Keterangan:

$\mathrm{E}<0 \%$ tidak diperlukan sistem proteksi petir $0 \%<\mathrm{E} \leq 80 \%$ berada pada tingkat proteksi IV $80 \%<\mathrm{E} \leq 90 \%$ berada pada tingkat proteksi III $90 \%<\mathrm{E} \leq 95 \%$ berada pada tingkat proteksi II $95 \%<\mathrm{E} \leq 98 \%$ berada pada tingkat proteksi I $\mathrm{E}>98 \%$ berada pada tingkat proteksi I dengan penambahan alat proteksi

Tabel 8. Hasil Perhitungan Beberapa Variasi

Pada gedung Rektorat UNY tampak depan (selatan) tahap I, II dan III, tampak samping timur dan tampak samping barat, untuk sistem penangkal petir eksternalnya menggunakan penangkal petir konvensional dengan panjang terminasi udara $1,4 \mathrm{~m}$ yang terletak dipuncak atap bangunan tertinggi yang berbentuk plana kuda.

Berdasarkan gedung tertinggi yaitu gedung Rektorat tampak depan (selatan) memiliki tinggi 26,6 $\mathrm{m}$ dan panjang terminasi udara adalah 1,4 m maka berdasarkan Tabel 2 bangunan tergolong dalam ketinggian $20 \mathrm{~m}$ 
sehingga sudut proteksinya 450 sehingga radius proteksinya dapat dihitung dengan:

$$
\begin{aligned}
& \alpha=\frac{r}{h} \\
& \mathrm{r}=\alpha \times h=\tan 45^{\circ} \times 28 \mathrm{~m}=28 \mathrm{~m}
\end{aligned}
$$

Jika dilakukan analisa yang serupa dengan langkah-langkah di atas dengan ketinggian gedung dan sudut yang berbedabeda sesuai dengan tingkat proteksi maka dapat dirincikan pada Tabel 9.

Tabel 9. Perhitungan Radius Penangkal Petir Konvensional dengan Metode Sudut Proteksi Untuk Beberapa Variasi Ketinggian

\begin{tabular}{|l|c|c|c|c|}
\hline \multicolumn{1}{|c|}{ Lokasi } & Sudut & $\begin{array}{c}\text { Tinggi Gedung + } \\
\text { Penangkal petir }\end{array}$ & $\begin{array}{c}\text { Radius } \\
\text { Proteksi }\end{array}$ & $\begin{array}{c}\text { Jumlah } \\
\text { Termina } \\
\text { si udara }\end{array}$ \\
\hline Depan selatan & & & & \\
\hline - Tahap I & Tan $45^{0}$ & $21,9 \mathrm{~m}$ & $21,9 \mathrm{~m}$ & 1 batang \\
\hline- Tahap II & Tan $45^{0}$ & $28 \mathrm{~m}$ & $28 \mathrm{~m}$ & 1 batang \\
\hline - Tahap III & Tan $45^{0}$ & $21,9 \mathrm{~m}$ & $21,9 \mathrm{~m}$ & 1 batang \\
\hline Samping timur & Tan $55^{0}$ & $18,95 \mathrm{~m}$ & $27,06 \mathrm{~m}$ & 2 batang \\
\hline Samping barat & Tan $55^{\circ}$ & $18,95 \mathrm{~m}$ & $27,06 \mathrm{~m}$ & 2 batang \\
\hline
\end{tabular}

Berdasarkan hasil analisa perhitungan penangkal petir konvensional dengan

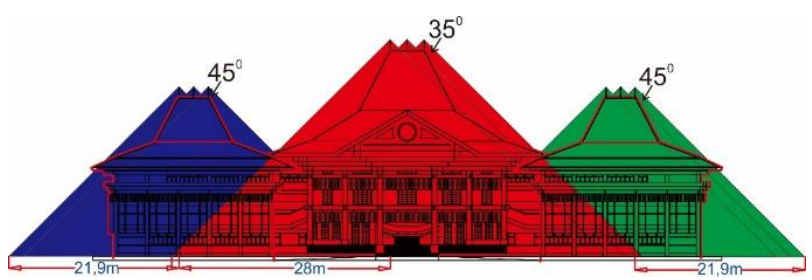

Gambar 1. Evaluasi radius penangkal petir dengan metode sudut proteksi gedung Rektorat UNY tampak depan tahap I, II dan III menggunaka metode sudut proteksi dengan panjang terminasi udara 1,4 meter, gedung Rektorat Universitas Negeri Yogyakarta tampak depan (selatan) tahap I, II dan III, tampak samping (timur) dan tampak samping (barat) belum mampu sepenunya melindungi bangunan dari sambaran petir. Perlindungan efektif adalah jika semua bagian bangunan/atap sudah terlindungi oleh penangkal petir atau berada dalam bidang segitiga proteksi.

Untuk mendapatkan perlindungan maksimal maka dilakukan evaluasi ulang dengan menggunakam metode yang sama dengan penambahan konduktor sebagai terminal tambahan yang dipasang pada garis bubungan atap dengan saling terubung sehingga berbentuk sangkar Faraday seperti pada Gambar 1, 2 dan 3.

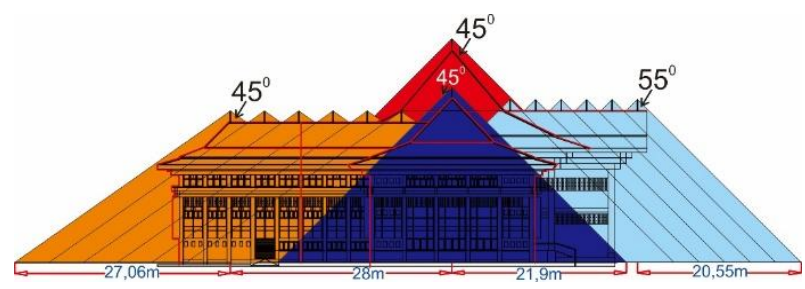

Gambar 2. Evaluasi radius penangkal petir dengan metode sudut proteksi gedung Rektorat UNY tampak samping (barat)

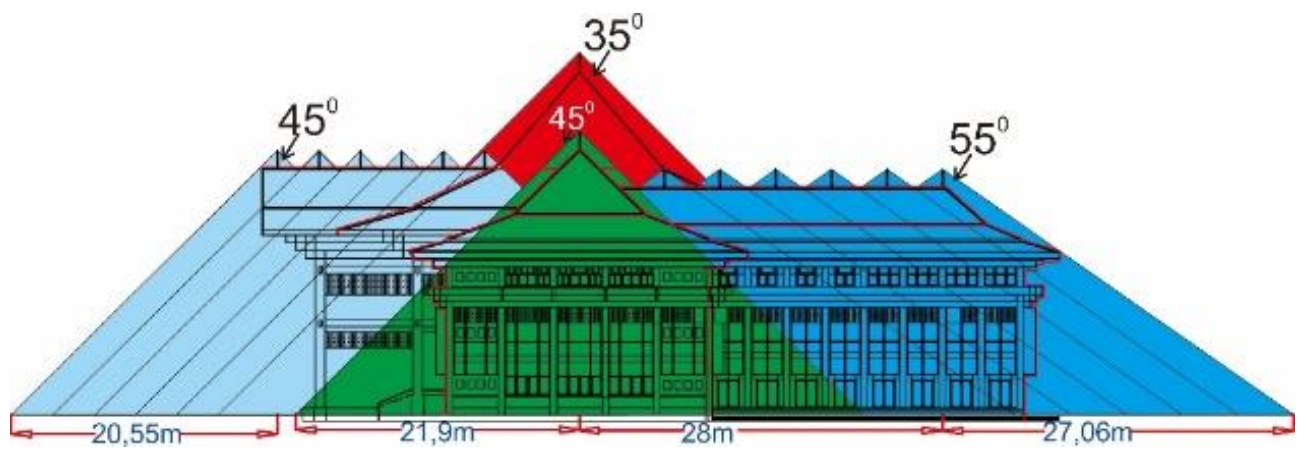

Gambar 3. Evaluasi radius penangkal petir dengan metode sudut proteksi gedung Rektorat UNY tampak samping (timur)

Hasil evaluasi sistem penangkal petir konvensional pada gedung Rektorat UNY tampak depan (selatan) tahap I, II dan III, tampak samping timur dan tampak samping barat dengan menggnakan metode sudut proteksi dapat dilihat pada Tabel 10. 
Tabel 10. Hasil Evaluasi Sistem Penangkal Petir Konvensional di Gedung Rektorat UNY

\begin{tabular}{|l|l|l|}
\hline No & \multicolumn{1}{|c|}{ Keadaan Semula } & \multicolumn{1}{|c|}{ Hasil Evaluasi } \\
\hline 1 & $\begin{array}{l}\text { Hanya digunaan 7 batang } \\
\text { terminasi udara setinggi } \\
1,4 \text { meter pada atap } \\
\text { gedung yang berbentuk } \\
\text { plana kuda }\end{array}$ & $\begin{array}{l}\text { Dibutuhkan terminasi udara tambahan } \\
\text { sebanyak 27 batang dengan panjang 1,4 } \\
\text { meter pada masing-masing atap yang } \\
\text { saling terhubung satu sama lain dengan } \\
\text { penyalur kebawah. }\end{array}$ \\
\hline 2 & $\begin{array}{l}\text { Masih terdapat titik } \\
\text { sambaran pada pada sisi- } \\
\text { sisi bangunan yang } \\
\text { berada di luar daerah } \\
\text { proteksi (bidang segitiga } \\
\text { proteksi) }\end{array}$ & $\begin{array}{l}\text { Atap bangunan yang membutuhkan } \\
\text { penangkal petir berdasarkan } \\
\text { perhitungan, telah terlindungi keculi } \\
\text { gedung rektorat tampak depan selatan } \\
\text { tahap II. Radius proteksi tidak mampu } \\
\text { menjangkau sisi atap bangunan, untuk } \\
\text { mengatasi hal tersebut dipasang kawat } \\
\text { konduktor pada bubungan atap yang } \\
\text { saling terhubung sebagai terminal } \\
\text { tambahan. }\end{array}$ \\
\hline
\end{tabular}

Penangkal petir Non-Konvensional (elektrostatis) yang terpasang pada atap gedung Rektorat UNY tampak depan (utara) yaitu jenis Helita Pulsar 60 No tipe IMH. 6012 dengan panjang terminasi udara $2 \mathrm{~m}$ (sudah termasuk terminal dan mounting) yang berjumlah 1 batang.

Radius penangkal petir yang terpasang yaitu 104 meter maka luas daerah proteksinya:

$$
\begin{aligned}
& \mathrm{Ax}=\pi \mathrm{x} \mathrm{r}^{2} \\
& \mathrm{Ax}=3,14 \times 104^{2} \\
& \mathrm{Ax}=3.3962,24 \mathrm{~m}^{2}
\end{aligned}
$$

Bangunan gedung rektorat tampak depan (utara) barada pada tingkat proteksi level III, Menurut NF C 17-102 besarnya D pada tingkat proteksi level III adalah 45 dan $\Delta \mathrm{T}$ ketika front time $60 \mu \mathrm{s}$ sehingga berdasarkan spesifikasi pulsar 60 nilai $\Delta$ adalah 60 .

$$
\begin{aligned}
h= & \text { (Bangunan tertinggi }- \text { Bangunan } \\
& \text { terendah }- \text { jarak atap dari bawah } \\
& \text { support final }+ \text { Tinggi Support } \\
& \text { terminasi udara } \\
h= & (20,78-7,24-2)+2=16 \\
\mathrm{D}= & 45 \mathrm{~m} \\
\Delta= & 60 \mathrm{~m} \\
\mathrm{Rp}= & \sqrt{2 r h-h^{2}+\Delta(2 D+\Delta)} \\
\mathrm{Rp}=\sqrt{\begin{array}{c}
2 \times 45 \times 13,54-13,54^{2} \\
+60(2 \times 45+60)
\end{array}} & \sqrt{\mathrm{Rp}=} 100 \mathrm{~m}
\end{aligned}
$$

Jika merujuk pada spesifikasi yang tertulis penangkal petir yang terpasang mempunyai radius proteksi sebesar $104 \mathrm{~m}$, namun pada kenyataannya bersasarkan perhitungan menggunakan standar NFC 17-102 hanya sekitar $100 \mathrm{~m}$ sehingga luas radius proteksinya menjadi:



Gambar 4. Radius penangkal petir elektrostatis gedung Rektorat UNY tampak depan (utara)

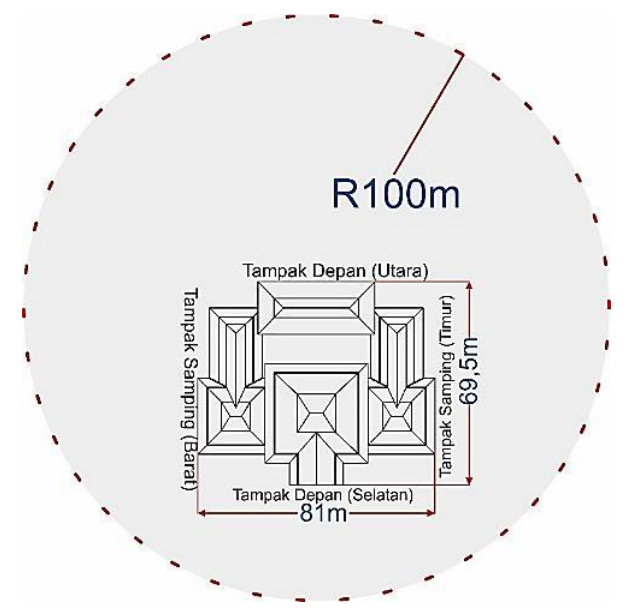

Gambar 5. Radius penangkal petir elektrostatis gedung Rektorat UNY depan (utara) tampak atas

Berdasarkan spesifikasi penangkal petir tersebut memiliki radius proteksi $104 \mathrm{~m}$ dan luas proteksi 33.962,24 $\mathrm{m}^{2}$ namun berdasarkan analisisa perhitungan menggunakan standar NFC 17-102 radius proteksinya sebesar $100 \mathrm{~m}$ dengan luas radius proteksi $31.400 \mathrm{~m}^{2}$. Itu berarti ada penurunan radius proteksi sebesar $3,8 \%$. Penurunan radius tersebut terjadi karena perhitungan berdasarkan standar NFC 17-102 perhitungan radius proteksi memperhitungkan adanya bangunan terendah disekitar lokasi. Meskipun radius yang terhitung berdasarkan standar NFC 17-102 hanya $100 \mathrm{~m}$, namun sudah mampu melindungi keseluruhan bangunan gedung Rektorat UNY seperti yang ditunjukan pada Gambar 5.

Konduktor penyalur yang terpasang pada penangkal petir konvensional dan 
nonkonvensional memiliki jenis yang sama yaitu kabel BC. Luas penampang penangkal konvensional yaitu $50 \mathrm{~mm}^{2}$ dan untuk nonkonvensional luas penampang yaitu 35 $\mathrm{mm}^{2}$. Penghantar ke bawah (down conductor) baik konvensional maupun nonkonvensional secara keseluruhan sudah sesuai ketentuan minimum NFC 17-102 dan SNI 03-7015-2004 yaitu konduktor penyalur untuk bahan tembaga minimum luas penampang yaitu $16 \mathrm{~mm}^{2}$.

Terminasi bumi penangkal petir konvensional bejenis elektroda batang berjumlah 7 buah yang dipasang paralel. Pengukuran tahanan pentanahan (R) dilakukan 3 kali pengukuran dengan rentang waktu per tiga hari, hasil dari pengukuran tahanan pembumian ditunjukan pada Tabel 11 .

Tabel 11. Hasil Pengukuran Tahanan Pentanahan Penangkal Petir Konvensional

\begin{tabular}{|c|c|c|c|c|c|c|c|c|}
\hline No & Tanggal & R1 & R2 & $\mathbf{R 3}$ & $\mathbf{R 4}$ & $\mathbf{R 5}$ & $\mathbf{R 6}$ & $\mathbf{R 7}$ \\
\hline 1 & 28 Mei 2015 & 3,8 & 1,4 & $\mathbf{4}$ & $\mathbf{1 , 8}$ & $\mathbf{1 , 1}$ & $\mathbf{1 , 7}$ & $\mathbf{1 , 6}$ \\
\hline 2 & 1 Juni 2015 & 2,2 & 2,5 & 3,7 & 1,2 & 0,5 & $\mathbf{1 . 7}$ & $\mathbf{1 , 6}$ \\
\hline 3 & 4 Juni 2015 & 2,3 & 2,5 & $\mathbf{4}$ & 4,2 & $\mathbf{1 , 9}$ & $\mathbf{1 , 7}$ & $\mathbf{1 , 6}$ \\
\hline \multicolumn{2}{|c|}{ R rata-rata } & $\mathbf{2 , 7 6}$ & $\mathbf{2 , 1 3}$ & $\mathbf{3 , 9}$ & $\mathbf{2 , 4}$ & $\mathbf{1 , 1 6}$ & $\mathbf{1 , 7}$ & $\mathbf{1 , 6}$ \\
\hline
\end{tabular}

Untuk menghitung total tahanan pentanahan peralel (Rtot) digunakan persaman sebagai berikut:

$$
\begin{aligned}
& R_{\text {tot }}=\frac{1}{\frac{1}{R 1}+\frac{1}{R 2}+\frac{1}{R 3}+\frac{1}{R 4}+\frac{1}{R 5}+\frac{1}{R 6}+\frac{1}{R 7}} \\
& R_{\text {tot }}=\frac{1}{\frac{1}{2,76}+\frac{1}{2,13}+\frac{1}{3,9}+\frac{1}{2,4}+\frac{1}{1,16}+\frac{1}{1,7}+\frac{1}{1,6}} \\
& R_{\text {tot }}=0,28 \Omega
\end{aligned}
$$

Terminasi bumi penangkal petir elektrostatis menggunakan terminasi bumi penangkal petir nonkonvensional bejenis elektroda batang berjumlah satu buah. Berdasarkan hasil pengukuran tahanan pentanahan untuk penangkal petir nonkonvensional yaitu $1,6 \Omega$.

Dengan demikian sistem terminasi bumi baik konvensional maupun nonkonvensional ditinjau dari tahan pentanahan sudah memenuhi ketentuan umum pada PUIL 2000 Pasal 3. 13.2. 10 untuk total keseluruhan nilai tahanan pentanahan tidak boleh lebih dari $5 \mathrm{ohm}$.

\section{SIMPULAN}

Berdasarkan gedung tertinggi, gedung Rektorat UNY memiliki perkiraan bahaya sambaran petir sangat besar sehingga sangat perlu adanya sistem penangkal petir dengan tingkat proteksi level III.

Penangkal petir konvensional yang terpasang pada atap gedung Rektorat tampak depan (selatan) tahap I, II dan III, tampak samping (barat) dan tampak samping (timur) berdasarkan analisa metode sudut proteksi masih membutuhkan peningkatan proteksi. Untuk meningkatkan proteksi dengan metode yang sama membutuhkan 27 batang penangkal petir dengan panjang $1,4 \mathrm{~m}$ yang saling terhubung membentuk sangkar Faraday. Sedangkan penangkal petir nonkovensional (elektrostatis) yang terpasang pada atap gedung Rektorat tampak depan (utara) berdasarkan analisa perhitungan menggunakan standar NCF 17-102 radius proteksinya $100 \mathrm{~m}$. Meskipun radius proteksi hanya $100 \mathrm{~m}$, namun sudah mampu melindungi seluruh gedung Rektorat UNY, sehingga tampa ada peningkatan proteksi pada penangkal petir konvensional bangunan sudah terlindungi karena seluruh bangunan Rektorat UNY masuk dalam radius/zona penangkal petir nonkonvensional

Konduktor penyalur baik penangkal petir konvensional maupun nonkonvensional secara keseluruhan sudah sesuai ketentuan minimum standar NFC 17-102 dan SNI 03-7015-2004. Sedangkan untuk sistem terminasi bumi konvensional dan nonkonvensional yang terpasang ditinjau dari tahanan pentanahan sudah memenuhi ketentuan PUIL 2000 Pasal 3. 13.2. 10 .

\section{DAFTAR RUJUKAN}

Asep Dadan. 2010. Optimasi Sistem Penangkal Petir Eksternal Menggunakan Jenis Early Streamer. Skripsi. Universitas Indonesia.

Ahmad Edy Syukral Siregar. 2008. Perancangan Sistem Proteksi Petir 
Pada Bangunan Gedung Perkantoran, Perumahan Dan Pendopo. Skripsi. Univesitas Gajah Mada Yogyakarta.

Aan Tabrani. 2009. Sistem Proteksi Penangkal Petir di Gedung PT Bhakti Wasantara Net Jakarta. Skripsi. Universitas Marcu Buana

Abdul Syakur, ddk. 2006. Sistem Proteksi Penangkal Petir Pada Gedung Widya Puraya. Jurnal. Universitas Diponogoro

Badan Standarisasi Nasional. (2004). Sistem Proteksi Petir Pada Bangunan Gedung (SNI 03-7015-2004). Jakarta: Badan Standarisasi Nasional

Bayu Purnomo. 2015. Penentuan Perlindungan Oleh Batang Penagkal Petir dengan Metode Sudut Perlindungan. Tesis. Universitas Gajah Mada. Yogyakarta.

Departemen Pekerjaan Umum Republik Indonesia. $1987 . \quad$ Pedoman Perencanaan Penangkal Petir. Jakarta: Departemen Pekerjaan Umum.

French Standar. 2011. French National Standar NFC 17-102. Diambil pada tanggal 12 Oktober 2015 dari http://id.scribd.com/doc/20738563/NFC $-17-$

102\#scribdhttps://www.google.co.id/url

Hery Setijasa. 2012. Penangkal Petir Ektrostatis dan Konvensional. Jurnal. Politeknik Negeri Semarang.

Main Catalog. Helita Lightning Protection System External Lightning Protection.
Diambil pada tanggal 17 Juli 2015 dari https://library.e.abb.com/public/0d06b5 f7a $4 a b c f 1983257 \mathrm{~d} 1200425 \mathrm{~d} 24 / 1 \mathrm{TXH} 0$ 00196C0202-

Helita\%20external\%20lightning\%20pr otection.pdf

Nedi Gunawan. 2011. Evaluasi Sistem Penangkal Petir Eksternal Gedung Bandara Fatmawati Soekarno Bengkulu dengan Metode Konvensional dan Elektrogeometri. Skripsi. Universitas Bengkulu.

Panitia Revisi PUIL. 2000. Persyaratan Umum Instalasi Listrik 2000. Jakarta: Yayasan PUIL.

Protech. 2007. Perbedaan Penangkal Petir Konvensional dan Elektrostatis (Radius) System. Diambil pada tanggal 10 September 2015 dari http://www.pasangpenangkalpetir.com/ 2014/01/perbedaan-penangkal petirkonvensional.html\#.VkrAUvkrI_4

Soli Akbar. 2009. Studi Tentang Sistem Penangkal Petir Pada BTS (Base Transceiver Station) (Aplikasi pada PT. Telkomsel-Banda Aceh). Tugas Akhir. Universitas Sumatra Utara. Medan.

Tri Bambang Lestarianto. 2002. Perancangan Sistem Proteksi Petir Eksternal Terhadap Sambaran Petir Langsung Pada Stasiun Meteorologi Batan Serpong. Skripsi. Universitas Gajah Mada Yogyakarta. 